\title{
22. SOME RESULTS OF THE INVESTIGATION OF INTERSTITIAL WATERS, DSDP LEG 35
}

O.V. Shishkina, P.P. Shirshov Institute of Oceanology, Academy of Sciences of the U.S.S.R., Moscow, U.S.S.R.

\section{INTRODUCTION}

The chlorinity (total chloride, bromide, and iodide), sodium, and potassium contents were determined for 12 interstitial water samples collected during Leg 35 of the Deep Sea Drilling Project. The interstitial water was extracted aboard ship from sediments cored at four sites in the Southeast Pacific Ocean. Samples were provided with the assistance of Joris Gieskes, who was a Leg 35 cruise participant. A portion of each sample (10$12 \mathrm{ml}$ ) was also given to V.V. Gordeev for iron and manganese determinations (Bogdanov et al., this volume).

The analyses were made by G.A. Pavlova; and data are presented in Table 1. Chlorinity and concentrations of sodium and potassium are expressed in both $\mathrm{mmol} / \mathrm{kg}$ and $\mathrm{g} / \mathrm{kg}$; the $\mathrm{Na} / \mathrm{Cl}$ and $\mathrm{K} / \mathrm{Cl}$ values are weight ratios based on $\mathrm{g} / \mathrm{kg}$.

\section{PROCEDURES}

The chlorinity was determined from 1-g aliquots of interstitial water by titration with a silver nitrate solution in the presence of a fluorescene indicator. Constant mixing of the solution was obtained with a magnetic stirrer. Accuracy of the titration is $0.01 \mathrm{ml}$ or $0.05 \%$, yielding an error of $0.25 \%$ of the determined value.

The sodium content was determined from 1-g aliquots by: precipitating it in the form of $\mathrm{NaZn}\left(\mathrm{UO}_{2}\right)_{3}$ $\left(\mathrm{C}_{2} \mathrm{H}_{3} \mathrm{O}_{2}\right)_{9} 6 \mathrm{H}_{2} \mathrm{O}$ with a large excess of reagent, filtration of the precipitate in Scott's crucibles No. 3 or No. 4 , washing under a slight vacuum with ethyl alcohol saturated with triple salt, and, finally, weighing the precipitates. At constant laboratory temperature accuracy of this technique is $\pm 0.5 \%$.

The potassium content was determined by the tetraphenyl boron method on 2-3 g samples. Potassium was precipitated upon elimination of organic substances and ammonium by means of tetraphenyl sodium at $p \mathrm{H} 2$. The precipitate was filtered through Scott's crucible No. 4, washed with a special liquid, dried at $120^{\circ} \mathrm{C}$, and weighed. Accuracy of this technique is $\pm 1 \%$.

\section{RESULTS}

The total range of chlorinity in the samples studied is $19.33-19.89^{\circ} \%$. At Site 323 the chlorinity increases with depth from $19.55^{\circ} \%$ ( $90 \mathrm{~m}$ subbottom) to $19.89^{\circ} \%$ ( $380 \mathrm{~m}$ subbottom), and its average is $19.64 \%$, (see Table 1 and Figure 1). At Site 324 (Figure 2) the chlorinity ranges between 19.33 and $19.63 \%$, and the average of the five samples is $19.51 \%$. Deviation from the average constitutes less than $0.3 \%$ which lies within the range of possible sampling and analytical error. Thus, the chlorinity of interstitial waters at Sites 323 and 324 appears neither to have changed with time nor to be substantially different from that of bottom waters of the present ocean.
The absolute sodium concentrations fluctuate between 465 , and $475 \mathrm{mmol} / \mathrm{kg}$ at Site 323 and 464 and $482 \mathrm{mmol} / \mathrm{kg}$ at Site 324 . The average concentrations are 470 and $469 \mathrm{mmol} / \mathrm{kg}$, respectively. The potassium content in the interstitial waters of Sites 323, 324, and 325 decreases with depth. The decrease is particularly pronounced at Site 324 where values decrease from 12.6 to $4.5 \mathrm{mmol} / \mathrm{kg}$ and the $\mathrm{K} / \mathrm{Cl}$ ratio drops from 0.025 to 0.009 . The potassium content also decreases at Site 323-although less vigorously-from 10.7 to 5.6 $\mathrm{mmol} / \mathrm{kg}$, and the $\mathrm{K} / \mathrm{Cl}$ ratio decreases downhole from 0.021 to 0.011 (Figures 1 and 2). The decrease in the concentration of potassium with increased depth has been noted by American authors and in sediments of abyssal oceans is usually accompanied by calcium enrichment and magnesium impoverishment (Manheim and Sayles, 1969).

Some preliminary conclusions based on the distribution of chlorinity, sodium and potassium (this paper), and ammonia, calcium, magnesium and excess alkalinity (Gieskes, this volume) are as follows:

The cation and anion balance indicates that a decrease in concentration of sulfates as a result of sulfate reduction must have developed at Site 323 to a depth of 380 meters and at Site 324 to a depth of 135 meters (Gieskes, this volume). The accumulation of ammonia in the interstitial waters, the concentration of which greatly increases with depth, also indicates that diagenesis of organic matter occurs within the sediments.

There is little change in the alkaline reserve which is apparently unrelated to the decreased amount of sulfate. It is, instead, controlled by the introduction of increased amounts of calcium into the interstitial water which will cause $\mathrm{CaCO}_{3}$ precipitation, thus decreasing the alkalinity. A thinly dispersed precipitate of $\mathrm{CaCO}_{3}$ was seen in the sediments from which the interstitial waters were extracted. Thus the change of the anionic content of interstitial water in both holes leads to a $1 \frac{1}{2}$ to 2 times downhole decrease in sulfate concentration, a slight increase of alkalinity values to a state in which the anionic content is represented principally by chlorine.

The cationic compositions, with the exception of sodium, changed greatly within the sampled intervals. The calcium content sharply increases downhole, and that of magnesium and potassium decreases (Figures 1 and 2). The calcium enrichment and magnesium impoverishment of the cationic content as a result of interaction between interstitial waters and sediments pose an interesting problem for further study.

\section{REFERENCE}

Manheim, F.T. and Sayles, F.L., 1969. Interstitial water studies on small core samples, Deep Sea Drilling Project, Leg 6. In Fischer, A.G., et al., Initial Reports of the Deep Sea Drilling Project, Volume 6: Washington (U.S. Government Printing Office), p. 811. 
TABLE 1

Chlorinity, Sodium, and Potassium Content of Interstitial Water, DSDP Leg 35

\begin{tabular}{|c|c|c|c|c|c|c|c|c|c|c|c|}
\hline \multirow[b]{2}{*}{ Site } & \multirow[b]{2}{*}{ Core } & \multirow[b]{2}{*}{ Section } & \multirow{2}{*}{$\begin{array}{l}\text { Subbottom } \\
\text { Depth }(\mathrm{m})\end{array}$} & \multicolumn{2}{|c|}{ Chlorinity } & \multicolumn{3}{|c|}{ Sodium } & \multicolumn{3}{|c|}{ Potassium } \\
\hline & & & & $\mathrm{mmol} / \mathrm{kg}$ & $\%$ & $\mathrm{mmol} / \mathrm{kg}$ & $\%$ & $\mathrm{Na} / \mathrm{Cl}$ Ratio & $\mathrm{mmol} / \mathrm{kg}$ & $\%$ & $\mathrm{~K} / \mathrm{Cl}$ Ratio \\
\hline 322 & 3 & 1 & 295 & 545 & 19.33 & 471 & 10.83 & 0.560 & 10.5 & 0.409 & 0.021 \\
\hline $\begin{array}{l}323 \\
323 \\
323 \\
323\end{array}$ & $\begin{array}{l}1 \\
3 \\
4 \\
7\end{array}$ & $\begin{array}{c}5 \\
\mathrm{CC} \\
\mathrm{CC} \\
3\end{array}$ & $\begin{array}{r}90 \\
280 \\
330 \\
380\end{array}$ & $\begin{array}{l}551 \\
550 \\
554 \\
560\end{array}$ & $\begin{array}{l}19.55 \\
19.50 \\
19.63 \\
19.89\end{array}$ & $\begin{array}{l}470 \\
465 \\
472 \\
475\end{array}$ & $\begin{array}{l}10.80 \\
10.70 \\
10.86 \\
10.91\end{array}$ & $\begin{array}{l}0.553 \\
0.549 \\
0.553 \\
0.548\end{array}$ & $\begin{array}{c}10.7 \\
6.2 \\
6.35 \\
5.6\end{array}$ & $\begin{array}{l}0.417 \\
0.242 \\
0.247 \\
0.219\end{array}$ & $\begin{array}{l}0.021 \\
0.012 \\
0.012 \\
0.011\end{array}$ \\
\hline $\begin{array}{l}324 \\
324 \\
324 \\
324 \\
324\end{array}$ & $\begin{array}{l}1 \\
2 \\
3 \\
4 \\
5\end{array}$ & $\begin{array}{l}5 \\
6 \\
5 \\
4 \\
2\end{array}$ & $\begin{array}{r}16.5 \\
54.5 \\
81.5 \\
108.5 \\
135.5\end{array}$ & $\begin{array}{l}545 \\
554 \\
551 \\
552 \\
548\end{array}$ & $\begin{array}{l}19.33 \\
19.63 \\
19.55 \\
19.59 \\
19.47\end{array}$ & $\begin{array}{l}471 \\
482 \\
464 \\
467 \\
464\end{array}$ & $\begin{array}{l}10.85 \\
11.10 \\
10.64 \\
10.71 \\
10.69\end{array}$ & $\begin{array}{l}0.561 \\
0.565 \\
0.544 \\
0.547 \\
0.549\end{array}$ & $\begin{array}{r}12.6 \\
7.8 \\
5.8 \\
4.8 \\
4.5\end{array}$ & $\begin{array}{l}0.494 \\
0.305 \\
0.226 \\
0.187 \\
0.177\end{array}$ & $\begin{array}{l}0.025 \\
0.016 \\
0.012 \\
0.010 \\
0.009\end{array}$ \\
\hline $\begin{array}{l}325 \\
325\end{array}$ & $\begin{array}{l}1 \\
3\end{array}$ & $\begin{array}{l}3 \\
3\end{array}$ & $\begin{array}{r}\sim 40 \\
\sim 180\end{array}$ & $\begin{array}{l}552 \\
554\end{array}$ & $\begin{array}{l}19.58 \\
19.63\end{array}$ & $\begin{array}{l}476 \\
478\end{array}$ & $\begin{array}{l}10.97 \\
10.99\end{array}$ & $\begin{array}{l}0.560 \\
0.559\end{array}$ & $\begin{array}{c}11.2 \\
9.07\end{array}$ & $\begin{array}{l}0.437 \\
0.354\end{array}$ & $\begin{array}{l}0.022 \\
0.018\end{array}$ \\
\hline
\end{tabular}
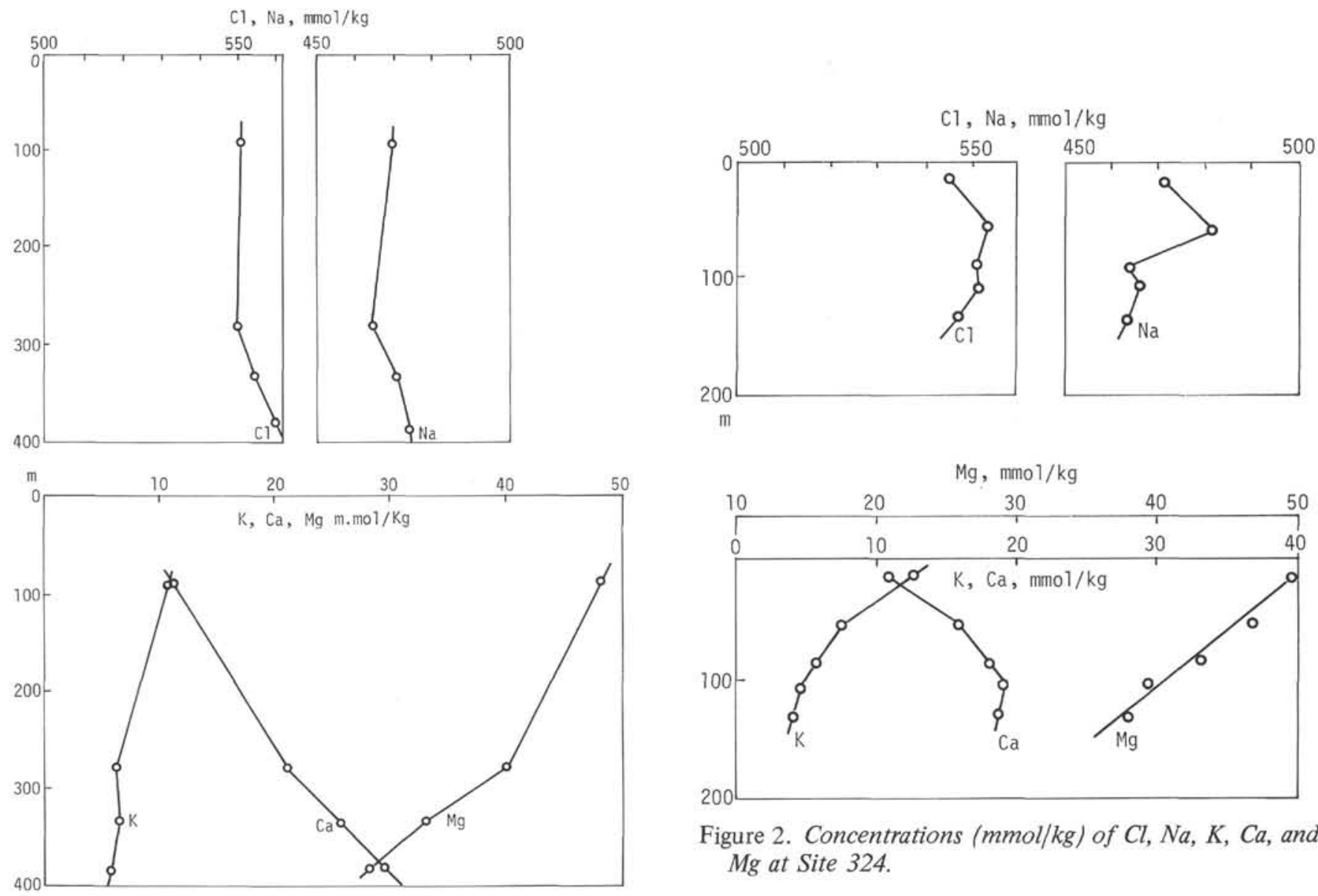

Figure 2. Concentrations $(\mathrm{mmol} / \mathrm{kg})$ of $\mathrm{Cl}, \mathrm{Na}, \mathrm{K}, \mathrm{Ca}$, and Mg at Site 324.

Figure 1. Concentration (mmol $/ \mathrm{kg})$ of $\mathrm{Cl}, \mathrm{Na}, \mathrm{K}, \mathrm{Ca}$ and $\mathrm{Mg}$ in interstitial water at Site 323. 